\title{
Rickettsia in the Regiment
}

Major R Stephenson

$M B, B S, D A, R A M C(V)$

Regimental Medical Officer, RHQ Royal Wessex Yeomanry, Cirencester, Gloucestershire

SUMMARY: A case of Rocky Mountain Spotted Fever (RMSF) is described, together with other cases of pyrexia whose occurrence originally gave the impression of a significant outbreak of the disease in a TA regiment after annual training in the USA. The role of the RMO is considered in such circumstances.

\section{Introduction}

The Royal Wessex Yeomanry (RWxY) was formed in 1971 by the amalgamation of three county Yeomanry Regiments - the Royal Wiltshire Yeomanry, the Royal Gloucestershire Hussars and the Royal Devon Yeomanry. TA centres were established in the principal towns of these three counties and in 1987 a composite squadron (Sqn) from these widely dispersed localities undertook an exchange exercise in the USA.

\section{Exercise Mulberry Tree}

The RWxY Sqn of 120 all ranks, joined a field exercise of the 45th Infantry Brigade, Oklahoma Army National Guard (OKARNG) in June 1987. The OKARNG Training Area, Camp Gruber, is situated in the Cookson Hills on the eastern border of Oklahoma State. It consists of dry grassland with areas of low deciduous woodland and smaller areas of swamp and damp ground. The average daily temperature in June is in the mid to high 30's on the Celsius scale, and there is a high humidity.

Before leaving, the RWxY Sqn were brought to a high level of physical fitness to reduce morbidity from the marked climatic change. Briefing concerned the problems of climatic adaption, fluid intake and the risks from snake and tick bites. The possibility of infection by a rickettsial organism was described, as RMSF is no longer confined to the Rocky Mountain area but is reported in practically all states of the USA, as well as Canada and parts of Central America. However, the highest incidence of 1000 cases between 1977 and $1980^{1}$ occurred in the "Old" South and Mid-West, including the Carolinas, Virginia, Georgia, Maryland, Tennessee and, most important for Exercise Mulberry Tree, Oklahoma.

RMSF was originally described in the nineteenth century in Montana, Idaho and Wyoming and was thought to follow tick bites in those individuals who were known to sleep on the ground whilst working in the developing Mid-West, such as bridge and railroad builders, carpenters and civil engineers ${ }^{2}$. The American pathologist H T Ricketts (1871-1910) first demonstrated rickettsial bodies as a cause for RMSF and described the wood tick as the route of transmission to the human ${ }^{3}$. He died of Mexican typhus whilst investigating its cause and spread.
The human rickettsioses are represented world-wide, occurring sporadically, and only occasionally producing epidemics when conditions are favourable, such as in Naples in World War II when epidemic typhus was transmitted by the louse because of poor hygienic conditions. The geographical distribution and arthropod vectors of the human disease are summarised in Table 1.

\section{Case Report}

For the duration of Exercise Mulberry Tree daily selfinspection for ticks was encouraged and a tick register was maintained by the Squadron Combat Medical Technician. During the fortnight, 72 persons reportes tick bites and the 'lone star' tick Amblyommer americanum, so called because of a white mark on the scutum of the female, was identified.

Within a week of returning 8 Yeoman became ill wit pyrexial illnesses and consulted their familg practitioners. All were able to report the risks of exposure to RMSF and all were investigated. Serum $\overrightarrow{0}$ from all three counties was sent by the Public Healtp Service Laboratories to its Special Pathogens Reference Laboratory at Porton Down in Wiltshire. A complete list of troops investigated was provided for the RMO, and one case of RMSF was confirmed by the Laboratory.

$L / C p l F$, aged 23 years, presented to his family doctor three days after returning to the $U K$ with a twenty four hour history of headache, fever and a rash. He detailed his movements over the previous two weeks, and the fact that he had been bitten by two ticks. He was admitted to the District General Hospital (DGH) where examination showed him to be generally well, but pyrexial $\left(37.8^{\circ} \mathrm{C}\right)$ with no neck stiffness or photophobia. He had a minimally injected oropharynx with tonsillar enlargement and lymphadenopathy in the left supraclavicular fossa and both inguinal regions. He also had an erythematous macular rash over his trunk, upper arms and legs. There were no haemorrhagic lesions.

On the day of admission his haemoglobin was $15.5 \mathrm{~g} / \mathrm{dl}$ and his total white cell count was $3.4 \times 10^{9} / 1$. There was also a slight thrombocytopenia $\left(97 \times 10^{9} / 1\right)$. His rickettsial antibody titre by indirect haemaglutination was negative for typhus group and that for spotted fever group was less than 1/80. He was treated with oral tetracycline (500mgs six hourly) and by the following day his 
Table 1

Rickettsial Diseases

\begin{tabular}{|c|c|c|c|}
\hline Disease & Rickettsia sp. & $\begin{array}{l}\text { Geographic } \\
\text { Distribution }\end{array}$ & $\begin{array}{l}\text { Arthropod } \\
\text { Vector Reservoir }\end{array}$ \\
\hline $\begin{array}{l}\text { Spotted Fever Group } \\
\text { Rocky Mountain Spotted Fever }\end{array}$ & R. rickettsii & $\begin{array}{l}\text { North, Central and } \\
\text { parts of Southern } \\
\text { America }\end{array}$ & Tick \\
\hline $\begin{array}{l}\text { Fièvre Boutonneuse } \\
\text { Kenya tick typhus } \\
\text { S. African tick fever } \\
\text { Indian tick typhus }\end{array}$ & R. conorii & $\begin{array}{l}\text { Mediterranean } \\
\text { Europe, Africa, India, } \\
\text { Middle East }\end{array}$ & Tick \\
\hline Queensland tick typhus & R. australis & Australia & Tick \\
\hline North Asian tick typhus & R. sibirica & Siberia, Mongolia & Tick \\
\hline Rickettsial pox & R. alcari & $\begin{array}{l}\text { America, Russia, } \\
\text { Korea, parts of Africa }\end{array}$ & Mite \\
\hline RMSF-like & R. canada & North America & Tick \\
\hline $\begin{array}{l}\text { Typhus Group } \\
\text { Epidemic typhus }\end{array}$ & R. prowazeki & $\begin{array}{l}\text { World-wide, mainly } \\
\text { S. America, Asia, } \\
\text { Africa }\end{array}$ & Louse \\
\hline Murine (endemic) typhus & R. mooseri & Worldwide & Flea \\
\hline Scrub typhus & R. tsutsugamushi & $\begin{array}{l}\text { Asia, Pacific Islands, } \\
\text { Japan, Australia }\end{array}$ & Mite \\
\hline $\begin{array}{l}\text { Others } \\
\text { Q Fever }\end{array}$ & Coxiella burnetii & Worldwide & $\begin{array}{l}\text { None (human } \\
\text { infection from } \\
\text { dust inhalation) }\end{array}$ \\
\hline Trench Fever & Rochalimaea quintana & Rare & Louse \\
\hline
\end{tabular}

condition had improved sufficiently to allow discharge home. His rash faded over the next few days.

His serology was repeated seventeen days after admission when the typhus group haemaglutination titre remained negative but the spotted fever group titre was now 1/160. This titre rise had probably been attenuated by the prompt tetracycline treatment, but it was considered significant enough to establish the diagnosis of RMSF.

Of the remaining seven cases, four reported general feelings of debility accompanied by a rash, two with either myalgia or mild arthralgia. Two of these soldiers were seen by the RMO and a fading maculopapular rash observed. A confident diagnosis of rubella was confirmed by raised rubella antibody titres. A third rash was reported to the RMO as being an excoriated rash from insect bites. None of the other three cases had a rash; two presented with pyrexia, malaise and generalised aches, but no firm diagnosis appeared to have been reached, and the last soldier presented with vertigo and was apyrrexial. His name did not appear on the Squadron list but he had convinced his GP that he had been at risk whilst exercising on Salisbury Plain with the UK exchange party of OKARNG! 
Discussion

The "hard ticks", Ixodidae (Fig 1), are recognised as both vectors and reservoirs of infections for several of the rickettsial diseases. RMSF is known to be spread by the wood tick Dermancentor andersoni and the dog tick Dermacentor variabilis as well as Amblyomma americanum. The brown dog tick Rhipicephalus sanguineus is known to transmit RMSF and fievre boutonneuse, as well as other rickettsial diseases. In the spring and summer months a delay of only 45-90 minutes after attachment is required for the tick to be considered infectious and during that time the body becomes engorged with blood of the host, increasing the number of rickettsia within the tick. It is also known that the excreta of ticks is infectious if rubbed in through abrasions in the skin.

The clinical aspects of RMSF, such as malaise, headache, pyrexia and rash, appear after an incubation period of 3-12 days and are a result of proliferation of rickettsiae in endothelial linings of small blood vessels, producing an inflammatory vasculitis. The rash, beginning in the extremities around the 3rd to 6th day, is a flat pink lesion which fades on pressure. It starts on the palms, soles, forearms and lower legs and over the next 48 hours spreads to the trunk and buttocks, giving a deeper red maculopapular appearance as it ages. In untreated cases the rash may become frankly haemorrhagic and eccymotic, the end result of endoangiitis. A mortality of $20 \%$ should be expected in untreated cases, mainly in the over 50 year age group, as a result of vascular collapse and circulatory failure. Neurological manifestation, such as hemiplegia and coma, may indicate rickettsial encephalitis.

Tetracycline, which is rickettsiostatic only, was introduced in 1948 and can improve the clinical picture within 48 hours. The initial oral dose should be $25 \mathrm{mg} / \mathrm{kg}$ body weight, followed by $500 \mathrm{mg} 6$ hourly, and this is continued until the patient has been afebrile for 24 hours. The rapid response to tetracycline is less marked if the rash has reached the haemorrhagic state. Severely debilitated patients will require intravenous tetracycline and $500 \mathrm{mg} 12$ hourly is given, reconstituted in sodium chloride or lactate. The maximum intravenous dose should not exceed $2 \mathrm{~g}$ daily.

The occurrence of cases of the spotted fever group of rickettsiae in Great Britain is relatively unusual. During the last two years 39 cases have been reported by the Special Disease Reference Laboratory and 37 of these were due to tick typhus Rickettsia conorii. Only two cases have been identified as RMSF (Rutter D A: Personal communication).

There are now well established exchanges between the TA and the National Guard of the USA and the parttime soldier has increasing opportunities to take part in overseas exercises. With the increase in travel comes the increased risk of exposure to fresh disease patterns. On returning to his home the civilian soldier naturally seeks advice from his family practitioner and the DGH when

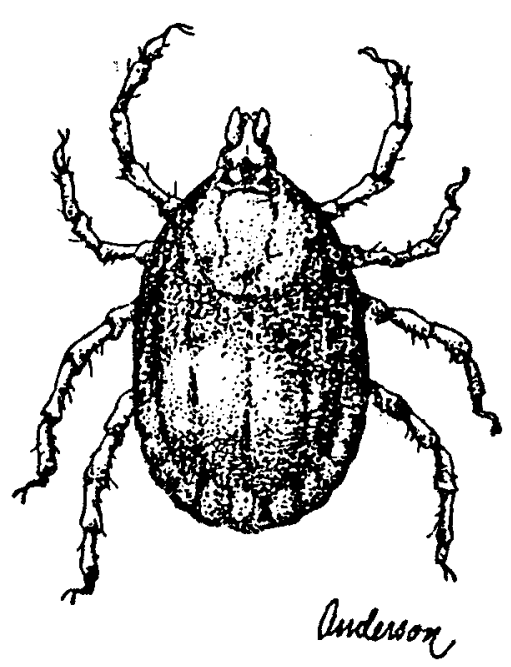

Fig. 1. Hard Tick (Ixodidae) Body Parts, scutum and capitulum, total 4-6 mm long.

Reproduced by permission from BECK, J WALTER, and BARRETT-CONNOR, E: Medical Parasitology 1971; The CV Mosby Co., St Louis, MO., USA.

medical problems arise. The TA RMO, with soldier scattered over a wide area, is therefore at a disadvantage compared with his regular colleague in that he is unable to initiate or control the investigation of any illnes contracted during the time abroad. His contribution therefore, can only be to provide full information to his. troops about possible exposure to known endemie pathogens in the country to be visited so that the sick soldier can present these facts to his own doctor.

Any strategy which heightens the general practitioner's suspicion must be welcomed, although, as in Exercise Mulberry Tree, it may lead to an exaggerated response. The author, however, considers this to be acceptable particularly in the light of recent cases of litigation for failure to diagnose an unusual disease. It has been established that a doctor may be negligent if he fails to consider the diagnosis of a tropical disease after a patient has returned from the tropics. The doctor "should be alert to the possibility that the disease might not be indigenous"4.

The RMO must see that he is involved from the early planning stages and have the opportunity to speak at the briefing for overseas exercises.

\section{Acknowledgement}

I should like to thank Dr D A Rutter of the Public Health Laboratory Service, Porton Down for his assistance, Dr D P Mullen, Salisbury General Infirmary, N for information about his patients, the general 
practitioners contacted during follow-up of the cases and Mrs Sue Davis for her secretarial assistance.

\section{REFERENCES}

1. WoODWARD T E. Oxford Textbook of Medicine, Oxford. Oxford University Press. 1982. 5.388.
2. MAYO H N. Rocky Mountain or Spotted Fever. JAMA 1947. 36:1906.

3. RICKETTS H. The Study of 'Rocky Mountain Spotted' (Tick Fever?) by means of animal inoculation. JAMA 1947. 33:1906.

4. ANNUAL Report. Medical Defence Union. London. 1986. pp 29-30.

\section{ABSTRACTS OF PUBLICATIONS}

\section{W OLLIER, J AWAD, D MCCLOSKEY, MAJOR T O JEFFERSON, RAMC and H FESTENSTEIN}

Ollier W, Awad J, McCloskey D, JefFerson T O and Festenstein H. HLA Antigens in Nepalese. Proceedings of the Third Asia-Oceania Histocompatability Workshop and Conference Sapporo, Japan June 27-July 1, 1986; 281-286.

Abstract: Blood was taken from a panel of Nepalese volunteers in order to study the distribution type and frequency of HLA antigens in Nepalese. The panel was made up of Nepalese soldiers serving in the British Army (Gurkhas).

Tissue typing carried out at the London Hospital showed that the Gurkhas on the donor panel, if representative of the whole Nepalese population, have few antigenic similarities with Caucasoid or Mongoloid populations.

To the authors' knowledge this study represents the first ever instance of HLA typing in Nepalese.
LT COL G E RATCLIFFE, RAMC

RAtCliffe G E. Amoebic Disease Precipitated by Corticosteroids Prescribed for Tuberculous Pleural Effusions. Tubercle 1988; 69: 219-221. Abstract: Despite negative stool examinations for cystso
or trophozoites of Entamoeba histolytica prior to
commencement of oral steriods to enhance resolution of
tuberculous pleural effusions, one case of amoebic
abscess of the liver and one case of amoebic dysentery
occurred within ten to twelve days of steroid therapy.
Both responded to routine therapy. Amoebic
fluorescent antibody titres were positive in each case but
such results do not necessarily confirm persistent
infestation.
In countries like Nepal where tuberculous pleural
effusion and amoebic disease are both common, such
cases must be expected to occur despite attempts to
exclude the amoebic carrier state. 